Проведено дослідження прочесу управління ресурсозабезпеченням діяльності підприємств з урахуванням гендерного фактору. Визначено, що съогодення вимагає від суб'єктів господарювання при управлінні ресурсним портфелем підприємства враховувати гендерний фактор. Дослідження ролі жінок в діяльності підприємства вказують на те, що у більшості випадків залучення жінок до діяльності підприємства відбувається не без прояву гендерних стеpeomunis.

Досліджено особливості впливу гендерних аспектів на ресурсозабезпеченість діяльності підприємства. Встановлено, що для кожного суб'єкта господарювання притаманні індивідуальні ресурсні комбінаиії, які формують ресурсну асиметрію та підвищують рівень конкурентоспроможності підприємства. Визначено, що причини посилення гендерної асиметрії обумовлюються факторами, а саме: розвитку сочіуму (демографічного, технологічного, сочіально-економічного); гендерного порядку (дискримінаціонним фактором); поведінковим. Здійснено ідентифікаціюо компонентів ресурсного портфеля з урахуванням наявного впливу гендерного фактору на ефективність бізнес-процесів. Принциповою новизною в систематизаціі елементів ресурсозабезпечення діяльності підприємства є отримання набору вагових коефічієнтів, що дозволяє оцінити ефективність функиіонування підприемств на підставі $i$ з урахуванням диференціаціі складових ресурсного портфеля.

Обгрунтовано доцільність використання методу вирішення цільового завдання управління ресурсозабезпеченням діяльності підприємств пивоварної промисловості, за рахунок визначення залежності показника ефективності функціонування підприємства від обсягів інвестування в приватні ресурси. Запропоновано побудувати матрицю прийняття рішень 3 використанням порівняльного підходу та визначених коефічієнтів вагомості елементів ресурсного дерева для оцінювання ефективності результатів ресурсозабезпеченості діяльності підприємств пивовар ної промисловості

Ключові слова: процеси управління ресурсозабезпеченістю, гендер, ресурсний портфель підприємства, ресурсна асиметрія, генерогенність

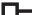

UDC 658.51

DOI: $10.15587 / 1729-4061.2018 .150799$

\section{PROCESS OF RESOURCES PROVISION MANAGEMENT OF THE ENTERPRISE'S ACTIVITY WITH CONSIDERATION OF GENDER FACTOR}

\author{
K. Andriush chenko \\ Doctor of Economic Sciences, Professor* \\ E-mail: katya373@i.ua \\ D. S t e f a n y $\mathbf{s}$ y $n$
}

Doctor of Technical Sciences, Professor, Lead Researcher Department of Natural Resources Institute of Telecommunications and Global Information Space Chokolivs'kyi blvd., 13, Kyiv, Ukraine, 03186

M. S a haid a k

Doctor of Economic Sciences, Professor*

M. Te pli u k

$\mathrm{PhD}$, Senior Lecturer*

O. B u c h y n s k a

$\mathrm{PhD}$, Senior Lecturer Department of Marketing**

E. Roz m e tov a

$\mathrm{PhD}$, Associate Professor

Department of Tourism and Hotel Business National University of Food Technologies Volodymyrska str., 68, Kyiv, Ukraine, 01601

T. Marusei $\mathrm{PhD}$

Department of Information Technologies State Agrarian and Engineering University in Podilya Schevchenko str., 13, Kamianets-Podilskyi, Ukraine, 32300

Ia. Levchenko

Doctor of Social Sciences and Economics, Assistant Department of Economics and Entrepreneurship Kharkiv National Automobile and Highway University Yaroslava Mudroho str., 25, Kharkiv, Ukraine, 61002

I. S m y r nova

Doctor of pedagogical sciences, associate professor Laboratory of technology of professional training of the Institute of vocational education and training of the NAESU Vito-Litovskyi lane, 98-a, Kyiv, Ukraine, 03045

T. Z h y t o m y r sk a $\mathrm{PhD}$, Associate Professor Department of General Pedagogy, Preschool, Primary and Special Education Izmail State Humanitarian University Repina str., 12, Izmail, Ukraine, 68610 *Department of Economics and Entrepreneurship** **Kyiv National Economic University named after Vadym Hetman Peremohy ave., 54/1, Kyiv, Ukraine, 03057

\section{Introduction}

Dynamic conditions of the market environment of the present require economic entities to apply modern methods of mathematical modeling when managing the resource portfolio of the enterprise. At the same time, when identifying the structure of such a portfolio and assessing the weight of its individual elements, the gender factor consideration can be important. 
Research on gender issues in entrepreneurship is usually limited to the study of the features of the so-called "male and female entrepreneurship" [1]. Generally, gender researchers analyze certain aspects of gender relations, however, without considering the fact that the review of any social, economic, political problem without regard to the gender component will be incomplete and one-sided. Most theorists and practitioners, referring to entrepreneurial activity, often mean "entrepreneurship with a male face". At the same time, taking into account the influence of the gender factor on the resource provision of the enterprise, in which successful teams are formed on the basis of gender equality, remain outside of the attention of scientists.

In most cases, the concept of "gender" in entrepreneurship is considered as a category where, within the limits of gender affiliation, qualitative characteristics of the position of women and men in society and the business environment are of importance. The business model, which is oriented to male resource availability at the enterprise, is still considered the most natural (basic) model for successful business. Investigating the role of women in the enterprise activity suggests that in most cases, the involvement of women in the enterprise activity is not without the emergence of gender stereotypes. These stereotypes are present in the description and quality of the standard definition of male or female; the content of the norms of the behavior scenarios, program-images, which are traditionally attributed to the male or female sex. They show general ideas, opinions about members of society about differences between men and women; depending on the context of the culture and the social environment in which they work and apply [2].

To date, women are still more likely to be engaged in housekeeping than men. So, according to sociological surveys, 56 percent of men spend at least half their time working to create their own business. While 43 percent of women said they spend most of their time on entrepreneurship, and 57 percent - spend more than half of their time with their families [3]. However, this difference is not that great, as reflected in the scientific publications of recent years. In particular, publications that relate to women's entrepreneurship examined the problems that affect the decrease of women activity in business and studied the peculiarities how women of various nationalities choose the professional activity [3].

Promotion of the ideology of gender equality and the representation of women in enterprise activities are increasingly being debated in society and in political discussions in different countries [1, 2]. However, despite the active efforts in the gender policy of democratic countries aimed at increasing the presence of women in enterprise activities, men continue to dominate. The results of research on the relationship between gender diversity and financial performance of enterprises are also ambiguous and require additional reflection [3, 4]. Therefore, the analysis and consideration of the role of the gender factor in the management of resource provision of enterprises is an important and topical issue.

Divergences obtained as a result of empirical research indicate that there is no conclusive evidence that there is a clear correlation between increased representation of women and enterprise activities. However, the experience of successful companies shows that the company's ability to effectively use intellectual resources, taking into account the gender factor, can stimulate the growth of resource value, form innovative competencies, and transform into sustainable competitive advantages [5]. Therefore, giving the proper attention to the gender factor in the development of a resource provision policy and adaptive methodology for identifying the importance of elements of the resource portfolio of the enterprise is an urgent task [6]. Its solution is possible within the framework of an integrated approach that allows taking into account the existing imbalances in dualistic resource characteristics, resource barriers, and the specifics of assessing the impact of each element of the resource portfolio in the context of modern gender policies.

\section{Literature review and problem statement}

The problem in [4] is the lack of a clear definition of the advantages or disadvantages of the gender aspect and the assessment of the impact of the gender factor on the functioning of the enterprise. In [7], a positive link between the participation of women in enterprise management is identified, the influence of women leaders on the psychological climate in the enterprise is revealed. But the focus is not on the key competences of the managers of these enterprises. The research presented in [8], on the basis of the revealed negative connections concerning the participation of women in the enterprise management process, suggests ways to improve the situation. On a global scale, business development is accompanied by the feminization of the labor market, increasing participation of women in economic activities, which definitely becomes more "flexible". According to research data in recent years, women's participation in the labor market has increased significantly, particularly in East Asia and the Pacific and in the Middle East. However, in spite of changing gender models in labor markets, the female model is often limited to the informal sector.

On the whole, the world economy is characterized by a rather high level of unemployment, both among men and women. At the same time, the percentage of unemployment among young women, unlike young men, is higher. Participation of young men in the labor market is considered more valuable. Although in the modern business space "female entrepreneurship" is heavily promoted, the vast share of investments is still destined for men, if not taking into account some regional differences. For example, women's property in developing countries is about $24 \%$ in Eastern Europe and Central Asia, and only about $3 \%$ in South Asia. Barriers faced by women are: different levels of education, social, cultural and religious restrictions and norms, lack of capital, unequal legal status, less political influence, etc. [14, 15].

The author [11] emphasized the absence of any link between the participation of women in the management of the enterprise and the results of its activities. Thus, the question of the relationship between the increase in the number of women in corporate roles and the results of the enterprise remains unresolved, as well as the question, in the case of such a connection, what resources have a positive impact, and what have a negative impact.

In general, scholars who are supporters of women's business divide problems into two groups of tasks of substantiation of gender diversity $[8,11]$ :

1) ethical substantiation;

2) business substantiation.

The first ones [11] argue that women need to be involved in any activity of the enterprise and in all positions based on the concept of equality. Noting [12] that such an action is not directly related to the increase of labor productivity, its 
purpose is to achieve greater participation of women, which is considered a positive and fair result of the development of the modern economic environment. In this case, a greater number of women in the enterprise does not (directly or indirectly) increase the efficiency of the company, but it is a positive factor, because, according to researchers, is a reflection of the "real world". At the same time, other factors of resource provision may have a more significant effect on improving the financial performance of the enterprise.

Several papers [5,11] focus on the manifestations of heterogeneity in business. It is noted that such a situation, which reflects contemporary realities in the gender issue, in general, has the potential for financial growth and successful development of the enterprise. It should only be taken into account that diversity (heterogeneity) has two sides of one "medal". Increasing diversity (female representatives) can have both positive [5] and negative [8] effect in the process of achieving the desired results. Positive and negative effects of diversity can also neutralize each other or depend on how they are managed.

For example [11], a sample of different characteristics from 45 points (e.g., age, gender, education, etc.) was made and the impact of these links with resource-provision factors on the productivity of the enterprise was conducted. However, in [11, 12], it is noted that various team members improve the company's activities by introducing wider bases of knowledge and experience. In [13, 14], it was shown that with increasing (gender) diversity in groups the available cognitive resources are expanded. Research materials $[15,16]$ indicate that if cognitive resources are used effectively, these resources are transformed into diverse perspectives that can contribute to the emergence of alternative solutions (diversification of solutions). This allows discovering new opportunities. In [17], the factors that are based on a cognitive structure with gender and relational demographic features that affect the processes of interpersonal and organizational nature, affecting the effectiveness of the enterprise as a whole, are considered. The variety of perspectives presented in [18] contributes to a more critical analysis of complex problems. Improving the difficult situation is proposed in $[1,9]$ by preventing premature management decisions, allowing creative and innovative solutions to be developed. Hence the conclusion is that an increase in the number of women at the enterprise can improve the financial performance of the company due to the diversification of prospects.

Researchers in their international publications [20, 21] carried out an analysis of the impact of gender and cultural differences on the efficiency of the enterprise and the development of competences among employees. In [20], studying gender dynamics and workplace conflicts, plausible apperception was achieved, paying particular attention to the role of expectations and consequences of decision-making by all parties involved in the enterprise. In [21], it is suggested that the possibility of gender differences should be taken into account when discussing conflict management at the workplace. The leadership should determine whether the conflict has gender roots, and whether it has a negative or positive effect on the productivity of the enterprise as a whole [22].

The author of the paper [23] argues that as soon as women had entered the labor market, the condemnation of women empowerment has begun. The corresponding value of gender differences factors in working conditions was reflected in the conflict behavior in the workplace, from the point of view of both sexes. Studies [24] led to topics such as the conflict of gender roles, organizational status and conflict of work style. There are two theoretical peculiarities for explaining conflicts of different sexes. These are peculiarities focused on the impact of gender role orientation, on the one hand, and on the other hand, it is the status within the organization. It is noteworthy that in [25] it is argued that empirical data on factors affecting gender differences in small enterprises did not occur, therefore, they were not taken into account at large by the researchers.

However, along with the fundamental scientific achievements obtained in [4-16], the fragmentation of research results that have practical relevance to determining the importance of the influence of the gender factor on resource provision of the enterprise is worth noting.

\section{The aim and objectives of the study}

The aim of the study is to determine the necessity and features of the resource management process of the enterprise activity, taking into account the gender factor, by developing a model for identifying the key elements of the enterprise resource portfolio.

To achieve the aim, the following objectives were set:

- to study the peculiarities of the influence of gender aspects on the resource provision of the enterprise;

- to propose a model of the resource management of the enterprise activity, taking into account the gender factor;

- to identify and systematize the elemental components of the resource portfolio of the enterprise to ensure the effectiveness of business processes in the enterprise;

- to substantiate the expediency of implementation of the developed model of identification of key elements of the resource portfolio for enterprises of the brewing industry of Ukraine.

\section{Theoretical and methodological principles of resource provision of the enterprise in the conditions of gender asymmetry}

4.1. General features of the gender factor manifestation in the processes of enterprise resource provision

Modern market conditions require enterprises to take operational managerial decisions on the determination of production volumes, the selection of target markets for product sales. Nowadays it is necessary to increase the efficiency of resource usage on the enterprise and create their optimal structure, which largely depends on the effectiveness of economic activity. This encourages enterprises to focus on using the opportunities of the market environment to find innovative resource combinations in order to gain sustainable competitive advantages [3].

A number of factors contribute to the activation of the relationship between men and women in the field of enterprise activity, namely:

1) gender belonging of the subjects of interaction as one of the primary criteria of social categorization in interpersonal and intergroup relations, which determines the definition of the physical boundaries of men and women groups;

2) socio-psychological density of men and women groups in the area of business interaction, where the proportion of women and men is almost the same, and competition contributes to the increase in the intensity of contacts of represen- 
tatives of these social groups. For example, it is fairly high in the food industry, especially in brewing.

The resource tree components are quite branched and focused on specific manifestations of intellectual peculiarities of individuals, in particular, taking into account the gender factor, which actualizes the research problem. Note that in the broadest sense, resources should be considered as a source of benefits through the accumulation of existing technological and socio-economic factors. In the context of resource provision of economic activities, "resources" are an integral part of the potential, the use of which allows achieving the goals and strategic development of the enterprise, (Fig. 1).

\begin{tabular}{|c|}
\hline NATURAL RESOURCES \\
\hline Exhaustible resources: people, plants, animals, minerals, soils, etc. \\
\hline Inexhaustible resources: water, sun, climate and other \\
\hline TRADITIONAL RESOURCES OF THE ENTERPRISE \\
\hline Material: land, real estate, equipment, inventory and others. \\
\hline Financial: investment, cash, receivables and payables \\
\hline Human: personal qualities, knowledge, skills, experience, reputation, habits, etc. \\
\hline MODERN RESOURCES OF THE ENTERPRISE \\
\hline Technological: patents, innovative technologies, receipes, industrial models, etc. \\
\hline Organizational: management structure, corporate culture, business processes, etc. \\
\hline Informational: information systems, databases, trade secrets, etc. \\
\hline Client: customer experience, customer base, formal coalitions, brand, etc. \\
\hline Gender: equality and non-discrimination, egalitarianism, social status, values, etc. \\
\hline
\end{tabular}

Fig. 1. Identification of resource elements in the context of the evolution of scientific views on the course of resource transformations

The UN has gender programs to promote enterprise development. These include targeted programs for women who seek greater gender equality, reducing gender violence, achieving peace between territories and in general, promoting social changes around the world [14]. It is noted that the involvement of women in enterprise activities is very important for the development of entrepreneurship.

Prerequisites for the emergence of gender asymmetry are usually sharp inflationary processes, the lack of a fullfledged demand for products and services, financial crises, increased resource constraints, and inefficient use of assets [15]. Our studies show that the reasons for the increase of gender asymmetry are due to the following factors, namely:

- Factors of society development (demographic, technological, socio-economic);

- Factors of gender (discriminatory factor);

- Behavioral factors [13].

In economic literature, gender issues are viewed under the prism of the economic rights of women and men and empowerment. In particular, one of the key features of gender manifestation is the acquisition and use of social capital in the sphere of interpersonal and institutional relations in the economic activity of the enterprise. Within the concept of a socially responsible business, gender equality is a key prerequisite for the formation of a positive image of the company, which emphasizes social norms, decent working conditions, access to resources, and others.

The growth of the employment rate of women in sectors dominated by men until recently reflects also non-formalization of earnings. It may be associated with poor working conditions and the flexibility of the working structure that can be offered to women for more competitive pricing among companies. Undoubtedly, not only free access to labor, but equal rights for women and men are a gender aspect of business development in many countries around the world. For example, the lack of land ownership for women in some countries may prevent them from accessing credit, since land is often used as a pledge. However, achieving more equal access to labor resources provides significant opportunities for both economic growth and the empowerment of women. Existing differences in gender rights have both direct and indirect effect on the development of the enterprise, especially given the trends of modern business.

\section{2. Methodical approaches to the es-} timation of the value of elements of the resource portfolio of the enterprise

Taking into account the key postulates of modern resource theory of entrepreneurship and the results of own scientific developments in this field [26], it should be noted that in order to determine the strategic direction in the enterprise activity, it is first necessary to identify the components of the resource portfolio that will provide this development. The phase of the structure modeling of the resource portfolio of the enterprise is necessary in order to further form optimal management decisions depending on the weight indices of individual resource elements [27, 28].

Let us consider the formal setting of the corresponding task. Let the value of the resulting parameter, which determines the efficiency of the enterprise, depend on the numerical values of some set of influencing factors $F=\left(F_{1}, F_{2}, \ldots, F_{n}\right)$. The corresponding analytical relation has the form

$$
y(F)=\sum_{i=1}^{n} w_{i} F_{i}
$$

The standard procedure for evaluating the values of vector elements $\mathrm{W}^{\mathrm{T}}=\left(w_{1}, w_{2}, \ldots, w_{n}\right)$ of weight coefficients is based on statistical processing of the results of a series of $N$ experiments, which determine the matrix of values of influential factors in each experiment and the vector of the values of the resulting parameter:

$$
\mathrm{H}=\left(\begin{array}{cccc}
F_{11} & F_{12} & \ldots & F_{1 n} \\
F_{21} & F_{22} & \ldots & F_{2 n} \\
\ldots & \ldots & \ldots & \ldots \\
F_{N 1} & F_{N 2} & \ldots & F_{N n}
\end{array}\right), \quad \mathrm{Y}=\left(\begin{array}{c}
y_{1} \\
y_{2} \\
\ldots \\
y_{N}
\end{array}\right)
$$

Then the least squares functional is introduced

$$
\mathrm{J}=(\mathrm{HW}-\mathrm{Y})^{\mathrm{T}}(\mathrm{HW}-\mathrm{Y}),
$$


the minimization of which gives the vector $\hat{W}$ of estimates of the weight coefficients, calculated by the formula

$$
\widehat{W}=\left(\mathrm{H}^{\mathrm{T}} \mathrm{H}\right)^{-1} \mathrm{H}^{\mathrm{T}} \mathrm{Y} \text {. }
$$

In many practical situations, the implementation of this idea is impossible due to the complexity of organizing and conducting an adequate number of experiments. The regression approach is successfully applied in solving numerous problems to describe the connection between the explanatory and explained variables. However, in this specific task of managing the resource provision of enterprises, its use is not effective. This is due to the lack of adequacy of linear regression models and the complexity of organizing and conducting an adequate number of experiments. In this regard, let us consider another well-known model.

Let a certain set of resources be used to ensure the effective functioning of the enterprise $\left(F_{j}\right), j=1,2, \ldots, n$. The indicator of enterprise efficiency can be calculated by the formula (Cobb-Douglas one), which has the form:

$$
R=\prod_{j=1}^{n}\left(F_{j}\right)^{w_{j}}
$$

where $w_{j}$ is the weight factor, which takes into account the importance of the $j$-th resource, $j=1,2, \ldots, n$.

This is appropriate in solving weakly structured decision making tasks under uncertainty, especially in complex cases where it is fundamentally impossible to carry out an objective assessment of the influence of certain factors on the system. This is due to the fact that they are subjective in nature and can be characterized by intrinsically contradictory and multicriteria data; the degree of influence (level of importance) of these factors is usually evaluated by expert methods.

Among the most effective expert methods for solving weakly structured decision-making problems with difficult formalized conditions, the method of T. Saati, which took the name "analytic hierarchy process" [29], and which was used in the study is distinguished. According to this method, the decomposition of a complex problem that is considered as a system into simpler components (elements, parameters) is carried out. With subsequent processing of the sequence of judgments of decision makers (experts), by pairwise comparisons of the importance of influencing factors. The method is implemented in the following way.

Let the enterprise efficiency depend on the numerical value of the influential factors (resources) in accordance with (1). Let us determine the importance of these factors. Based on the expertise, the matrix A of pairwise comparisons of significance (weight) factors is formed

$$
\mathrm{A}=\left(\begin{array}{ccccc}
1 & a_{12} & a_{13} & \ldots & a_{1 n} \\
a_{21} & 1 & a_{23} & \ldots & a_{2 n} \\
\ldots & \ldots & \ldots & \ldots & \ldots \\
a_{n 1} & a_{n 2} & a_{n 3} & \ldots & 1
\end{array}\right),
$$

where $a_{i j}$ is the number that determines the level of advantage of the resource $i$ compared to the resource $j$, and

$$
a_{i i}=1, \quad a_{j i}=\left(a_{i j}\right)^{-1}, \quad i=1,2, \ldots, n ; \quad j=1,2, \ldots, n .
$$

For the matrix obtained, the eigenvalue problem is solved. In this case, the characteristic equation is formed

$$
\operatorname{det}\left(\begin{array}{ccccc}
1-\lambda & a_{12} & a_{13} & \ldots & a_{1 n} \\
a_{21} & 1-\lambda & a_{23} & \ldots & a_{2 n} \\
\ldots & \ldots & \ldots & \ldots & \ldots \\
a_{n 1} & a_{n 2} & a_{n 3} & \ldots & 1-\lambda
\end{array}\right)=0
$$

the solution of which gives the set $\lambda_{1}, \lambda_{2}, \ldots, \lambda_{n}$ of eigenvalues of this matrix. After that, the desired normalized eigenvector $\mathrm{W}$ of this matrix corresponding to the maximum eigenvalue is found $\lambda_{\max }=\max \left(\lambda_{1}, \lambda_{2}, \ldots, \lambda_{n}\right)$. Let the result of the solution be the eigenvector $\mathrm{W}=\left(w_{1}, w_{2}, \ldots, w_{n}\right)$. If the matrix $\mathrm{A}$ correctly displays the relation between the importance of resources, then the components of the vector $w_{1}, w_{2}, \ldots, w_{n}$, have the meaning of weight coefficients that characterize their relative importance. Indeed, let the known weight coefficients $w_{1}, w_{2}, \ldots, w_{n}$, which specify the significance (importance, value) of resources. Then the significance of the $i$-th resource compared to the $j$-th one is estimated by the formula

$$
a_{i j}=\frac{w_{i}}{w_{j}}, j=\overline{1, n}
$$

At the same time, of course,

$$
a_{i j} a_{j k}=\frac{w_{i}}{w_{j}} \frac{w_{j}}{w_{k}}=\frac{w_{i}}{w_{k}}=a_{i k}, \quad a_{j i}=\frac{w_{j}}{w_{i}}=\frac{1}{\frac{w_{i}}{w_{j}}}=\frac{1}{a_{i j}} .
$$

The matrix A, whose components satisfy (3), is called coherent.

From (2) we get

$$
a_{i j} \frac{w_{j}}{w_{i}}=1, \quad \mathrm{i}, j=\overline{1, n}
$$

and, consequently,

$$
\sum_{j=1}^{n} a_{i j} w_{j} \frac{1}{w_{i}}=\frac{1}{w_{i}} \sum_{j=1}^{n} a_{i j} w_{j}=n, \quad \sum_{j=1}^{n} a_{i j} w_{j}=n w_{i} .
$$

Based on this, for an inverse symmetric positive coordinated matrix A there is the eigenvalue equal to $n$ and the corresponding positive eigenvector $\mathrm{W}$, whose components are the weights of the elements. Thus, if the matrix A, whose components satisfy (3) is given, then, the unknown vector W can be obtained by calculating the eigenvector of this matrix corresponding to its eigenvalue equal to $n$. However, this vector can also be obtained in a simpler way.

In accordance with (2), the matrix $A$ looks like

$$
\mathrm{A}=\left(\begin{array}{cccc}
\frac{w_{1}}{w_{1}} & \frac{w_{1}}{w_{2}} & \ldots & \frac{w_{1}}{w_{n}} \\
\frac{w_{2}}{w_{1}} & \frac{w_{2}}{w_{2}} & \ldots & \frac{w_{2}}{w_{n}} \\
\cdots & \ldots & \ldots & \ldots \\
\frac{w_{n}}{w_{1}} & \frac{w_{n}}{w_{2}} & \ldots & \frac{w_{n}}{w_{n}}
\end{array}\right) .
$$


Let us calculate the sum of the elements for each of the rows of the matrix. For arbitrary $i$ - th line we have

$$
\sum_{j=1}^{n} a_{i j}=\sum_{j=1}^{n} \frac{w_{i}}{w_{j}}=w_{i} \sum_{j=1}^{n} \frac{1}{w_{j}}=C w_{i}, \quad i=\overline{1, n} .
$$

Relation (4) results in the eigenvector $\mathrm{W}$, which can be calculated with accuracy up to constant directly by the elements of the matrix A. The constant $C$ is determined, based on the natural requirements for the vector $\mathrm{W}$ :

$$
\sum_{i=1}^{n} w_{i}=1
$$

Let's summarize the components of the left and right sides of the ratio (4) by $i$. In this case, taking into account (5), we obtain

$$
\begin{gathered}
\sum_{i=1}^{n} \sum_{j=1}^{n} a_{i j}=\sum_{i=1}^{n} C w w_{i}=C \sum_{i=1}^{n} w_{i}=C, \\
w_{i}=\frac{1}{C} \sum_{j=1}^{n} a_{i j}=\frac{\sum_{j=1}^{n} a_{i j}}{\sum_{i=1}^{n} \sum_{j=1}^{n} a_{i j}}, \quad i=\overline{1, n} .
\end{gathered}
$$

It is easy to check that the vector

$$
\mathrm{W}^{\mathrm{T}}=\left(\begin{array}{llll}
w_{1} & w_{2} & \ldots & w_{n}
\end{array}\right),
$$

obtained in accordance with (6) is the eigenvector of the matrix A corresponding to its eigenvalue equal to $n$. Indeed, we will calculate it

$$
\begin{aligned}
& A w=\left(\begin{array}{cccc}
\frac{w_{1}}{w_{1}} & \frac{w_{1}}{w_{2}} & \ldots & \frac{w_{1}}{w_{n}} \\
\frac{w_{2}}{w_{1}} & \frac{w_{2}}{w_{2}} & \ldots & \frac{w_{2}}{w_{n}} \\
\ldots & \ldots & \ldots & \ldots \\
\frac{w_{n}}{w_{1}} & \frac{w_{n}}{w_{2}} & \ldots & \frac{w_{n}}{w_{n}}
\end{array}\right) \cdot\left(\begin{array}{c}
\sum_{j=1}^{n} \frac{w_{1}}{w_{j}} \\
\sum_{j=1}^{n} \frac{w_{2}}{w_{j}} \\
\ldots \\
\sum_{j=1}^{n} \frac{w_{n}}{w_{j}}
\end{array}\right) \cdot \frac{1}{\sum_{i=1}^{n} \sum_{j=1}^{n} \frac{w_{i}}{w_{j}}}= \\
& =\frac{1}{\sum_{i=1}^{n} \sum_{j=1}^{n} \frac{w_{i}}{w_{j}}} \cdot\left(\begin{array}{c}
\sum_{j=1}^{n}\left(\frac{w_{1}}{w_{j}} \sum_{i=1}^{n} \frac{w_{i}}{w_{j}}\right) \\
\sum_{j=1}^{n}\left(\frac{w_{2}}{w_{j}} \sum_{i=1}^{n} \frac{w_{i}}{w_{j}}\right) \\
\sum_{j=1}^{n}\left(\frac{w_{n}}{w_{j}} \sum_{i=1}^{n} \frac{w_{i}}{w_{j}}\right)
\end{array}\right)=\frac{n}{\sum_{i=1}^{n} \sum_{j=1}^{n} \frac{w_{i}}{w_{j}}} \cdot\left(\begin{array}{c}
\sum_{j=1}^{n} \frac{w_{1}}{w_{j}} \\
\sum_{j=1}^{n} \frac{w_{2}}{w_{j}} \\
\ldots \\
\sum_{j=1}^{n} \frac{w_{2}}{w_{j}}
\end{array}\right)=n w,
\end{aligned}
$$

which was required. Components of $\mathrm{W}$ are used to calculate the enterprise efficiency in accordance with (1).

It is clear that the relation (6) will allow accurate estimation of the weights of the compared parameters only if the matrix $A$ is coherent. However, in practice, the matrix A, which contains the results of pairwise comparisons of the significance of the features that are formed by experts, of course, is not coherent.
Let the vector be implemented in order to solve a specific task of assessing the efficiency of enterprise activity.

$$
F i=\left(F_{M R} ; F_{F R} ; F_{C R} ; F_{O R} ; F_{H R} ; F_{T R} ; F_{G R}\right) \text {, }
$$

where $F_{M R}$ is the component of the vector for the parameter "material resources"; $F_{F R}$ is the component of the vector for the parameter "financial resources"; $F_{C R}$ is the component of the vector for the parameter "client resources"; $F_{O R}$ is the component of the vector by the parameter "structural resources"; $F_{H R}$ is the component of the vector for the parameter "human resources"; $F_{T R}$ is the component of the vector for the parameter "technological resources"; $F_{G R}$ is the component of the vector for the parameter "gender resources".

For this set of components of the vector F, by expert evaluation, we obtain the matrix A of pairwise comparisons of the importance of resources, summarized in Table 1.

Table 1

Matrix of pairwise comparisons of importance of resources

\begin{tabular}{|c|c|c|c|c|c|c|c|}
\hline $\mathrm{F}_{\mathrm{MR}}$ & 1 & 2 & 6 & 12 & 4 & 3.5 & 6 \\
\hline $\mathrm{F}_{\mathrm{FR}}$ & 0.5 & 1 & 3.5 & 7 & 2 & 1.5 & 3.1 \\
\hline $\mathrm{F}_{\mathrm{CR}}$ & 0.166 & 0.286 & 1 & 2 & 0.5 & 0.5 & 0.8 \\
\hline $\mathrm{F}_{\mathrm{OR}}$ & 0.083 & 0.143 & 0.476 & 1 & 0.25 & 0.35 & 0.45 \\
\hline $\mathrm{F}_{\mathrm{HR}}$ & 0.25 & 0.5 & 2 & 4 & 1 & 0.8 & 1.5 \\
\hline $\mathrm{F}_{\mathrm{TR}}$ & 0.286 & 0.666 & 2 & 2.86 & 1.25 & 1 & 1.5 \\
\hline $\mathrm{F}_{\mathrm{GR}}$ & 0.166 & 0.32 & 1.25 & 2.22 & 0.667 & 0.667 & 1 \\
\hline
\end{tabular}

The received expert matrix is inversely symmetric, but not coherent. For example,

$$
\begin{aligned}
& a_{13} \cdot a_{32}=6 \cdot 0,286=1,716 \neq a_{12}=2, \\
& a_{23} \cdot a_{31}=3,5 \cdot 0,166=0,581 \neq a_{21}=0,5, \\
& a_{43} \cdot a_{35}=0,476 \cdot 0,5=0,238 \neq a_{45}=0,25, \\
& a_{54} \cdot a_{46}=4 \cdot 0,35=1,4 \neq a_{56}=0,8, \\
& a_{56} \cdot a_{62}=0,8 \cdot 0,666=0,533 \neq a_{52}=0,5, \\
& a_{47} \cdot a_{75}=0,45 \cdot 0,667=0,3 \neq a_{45}=0,25, \\
& a_{76} \cdot a_{62}=0,667 \cdot 0,666=0,444 \neq a_{72}=0,32 .
\end{aligned}
$$

Here, for convenience, the elements of the matrix are numbered according to their position in it.

If the matrix of the pairwise comparisons of the importance of the relation coefficients (1) is not consistent, then the vector determined in accordance with (6) estimates the weight coefficients with the error the greater the stronger the real matrix A will differ from the coherent one. In this connection, we will put the problem of finding the matrix $\mathrm{X}$ satisfying two requirements: it should be consistent and minimally different from the matrix obtained from the averaging of the matrices produced by the experts.

Let

$\mathrm{A}=\left(a_{i j}\right), i=\overline{1, n}, j=\overline{1, n}-$ the original matrix of pairwise comparisons.

$\mathrm{X}=\left(x_{i j}\right), i=\overline{1, n}, j=\overline{1, n}-$ the coherent matrix, which was searched for pairwise comparisons. 
A formal statement of the problem: to find the matrix X that minimized

$$
F(x)=\sum_{i=1}^{n} \sum_{j=1}^{n}\left(x_{i j}-a_{i j}\right)^{2}
$$

and satisfied the constraints

$$
\frac{1}{n} \sum_{k=1}^{n} x_{i k} x_{k j}=x_{i j}, \quad i=\overline{1, n}, \quad j=\overline{1, n} .
$$

To solve the problem, we use the Lagrange's method of undetermined multipliers. Lagrange's function:

$$
\Phi(x, \lambda)=\sum_{i=1}^{n} \sum_{j=1}^{n}\left(x_{i j}-a_{i j}\right)^{2}+\sum_{i=1}^{n} \sum_{j=1}^{n} \lambda_{i j}\left(\frac{1}{n} \sum_{k=1}^{n} x_{i k} x_{k j}-x_{i j}\right)
$$

Taking the partial derivatives from (8) based on the task variables and equating them to zero, we obtain the system of equations

$$
\begin{aligned}
& \frac{\partial \Phi(x, \lambda)}{\partial x_{i j}}=2\left(x_{i j}-a_{i j}\right)+\lambda_{i j}\left[\frac{1}{n}\left(x_{i i}+x_{j j}\right)-1\right]=0, \\
& i=\overline{1, n}, \quad j=\overline{1, n} \\
& \frac{\partial \Phi(x)}{\partial \lambda_{i j}}=\frac{1}{n} \sum_{k=1}^{n} x_{i k} x_{k j}-x_{i j}=0, \quad i=\overline{1, n}, \quad j=\overline{1, n} .
\end{aligned}
$$

As $x_{i i}=x_{j j}=1$, then from (9) we should:

$$
2\left(x_{i j}-a_{i j}\right)-\frac{\lambda_{i j}(n-2)}{n}=0,
$$

where

$$
x_{i j}=a_{i j}-\frac{\lambda_{i j}(n-2)}{n}, i=1,2, \ldots, n, \quad j=1,2, \ldots, n .
$$

The solution to this system gives the set $\lambda_{i j}$, the substitution of which in (11) allows us to calculate the elements of the sought matrix of pairwise comparisons of the importance of resources.

Note, however, that the resulting nonlinear system of equations (12) can only be solved numerically, and the complexity of the solution to this problem grows rapidly with increasing dimensionality of the problem. In connection with this, in order to obtain a coherent matrix we use the inertial procedure proposed in [30]. This procedure is implemented as follows.

We use the fact that in the matrix A for all pairs $i, j$, equalities are fulfilled

$$
\begin{aligned}
& a_{i j}=a_{i k} a_{k j}, \\
& n a_{i j}=\sum_{k=1}^{n} a_{i k} a_{k j}, \\
& a_{i j}=\frac{1}{n} \sum_{k=1}^{n} a_{i k} a_{k j}, \quad i=\overline{1, n}, \quad j=\overline{1, n}, \quad \mathrm{k}=\overline{1, n} .
\end{aligned}
$$

This relation, together with the set of equality

$$
\begin{aligned}
& a_{i j}=\left(a_{j i}\right)^{-1}, \\
& i=\overline{1, n}, \quad j=\overline{1, n},
\end{aligned}
$$

defines a coherent matrix. Since the real matrix of pairwise comparisons has only the property (14), but does not satisfy (13), the procedure for correction of the real matrix approximating this matrix to the coherent one is proposed. It is clear that for any matrix A whose elements satisfy (13), the diagonal elements of the matrix

$$
\frac{1}{n} A A=A_{1}=\left\{a_{i j}^{(1)}\right\}
$$

are equal to 1 . Indeed, according to (13).

$$
a_{i i}^{(1)}=\frac{1}{n} \sum_{k=1}^{n} a_{i k} \cdot a_{k i}=\frac{n}{n}=1, \quad i=\overline{1, n} .
$$

The correction procedure is iterative. Each iteration takes three steps.

Let 1 iteration of correction be performed, which results in the matrix $\mathrm{A}_{1}$.

For the next $(l+1)$-th iteration, the following calculations are performed.

Step 1

We calculate

$$
\frac{1}{n} A_{l} A_{l}=\hat{A}_{l+1}=\left\{\hat{a}_{i j}^{(l+1)}\right\} .
$$

Step 2

We calculate

$$
\begin{aligned}
& a_{i j}^{(l+1)}=\frac{\hat{a}_{i j}^{(l+1)}}{\left(\hat{a}_{i j}^{(l+1)} \cdot \hat{a}_{j i}^{(l+1)}\right)^{\frac{1}{2}}}, \\
& a_{j i}^{(l+1)}=\frac{\hat{a}_{j i}^{(l+1)}}{\left(\hat{a}_{i j}^{(l+1)} \cdot \hat{a}_{j i}^{(l+1)}\right)^{\frac{1}{2}}} .
\end{aligned}
$$

It is clear that as a result of the transformation (16), the matrix $\mathrm{A}_{l+1}$ will satisfy (14), which, according to (15), ensures the equality of the diagonal elements of the matrix $\mathrm{A}_{l+2}$, which will be obtained at the next step, to 1 . Since the original matrix had the property (14), then, obviously, all the following matrices $A_{1}, A_{2}, \ldots, A_{l}, \ldots$, taking into account (15), will have the same property.

Step 3

We calculate

$$
\eta_{l}=\max _{i, j}\left|a_{i j}^{(l)}-a_{i j}^{(l+1)}\right| .
$$

If the value $\eta_{l}<\varepsilon$, where $\varepsilon$ is some rather small predetermined number (for example, $\varepsilon=10^{-2}$ ) is obtained, then the procedure can be considered complete. Otherwise, you should proceed to the next iteration.

We use the described procedure to reconcile the matrix of pairwise comparisons given in Table 1. As a result of two iterations, we obtain the following matrix (Table 2). 
Table 2

Matrix of pairwise comparisons

\begin{tabular}{|c|c|c|c|c|c|c|c|}
\hline & $\mathrm{F}_{\mathrm{MR}}$ & $\mathrm{F}_{\mathrm{FR}}$ & $\mathrm{F}_{\mathrm{CR}}$ & $\mathrm{F}_{\mathrm{OR}}$ & $\mathrm{F}_{\mathrm{HR}}$ & $\mathrm{F}_{\mathrm{TR}}$ & $\mathrm{F}_{\mathrm{GR}}$ \\
\hline $\mathrm{F}_{\mathrm{MR}}$ & 1 & 1.91 & 7.1 & 13.8 & 4.67 & 3.82 & 6.1 \\
\hline $\mathrm{F}_{\mathrm{FR}}$ & 0.524 & 1 & 3.72 & 7.23 & 2.49 & 2 & 3.2 \\
\hline $\mathrm{F}_{\mathrm{CR}}$ & 0.141 & 0.269 & 1 & 1.94 & 0.66 & 0.54 & 0.86 \\
\hline $\mathrm{F}_{\mathrm{OR}}$ & 0.072 & 0.138 & 0.52 & 1 & 0.34 & 0.275 & 0.44 \\
\hline $\mathrm{F}_{\mathrm{HR}}$ & 0.214 & 0.402 & 1.52 & 2.94 & 1 & 0.81 & 1.31 \\
\hline $\mathrm{F}_{\mathrm{TR}}$ & 0.262 & 0.5 & 1.85 & 3.64 & 1.234 & 1 & 1.6 \\
\hline $\mathrm{F}_{\mathrm{GR}}$ & 0.164 & 0.313 & 1.16 & 2.27 & 0.763 & 0.625 & 1 \\
\hline
\end{tabular}

This matrix is practically coherent. Indeed,

$$
\begin{aligned}
& a_{13} \cdot a_{32}=7,1 \cdot 0,269=1,909 \cong 1,91, \\
& a_{23} \cdot a_{31}=3,72 \cdot 0,141=0,525=a_{21}=0,524, \\
& a_{34} \cdot a_{46}=1,94 \cdot 0,275=0,5345 \cong a_{21}=0,54, \\
& a_{43} \cdot a_{35}=0,52 \cdot 0,66=0,343 \cong a_{45}=0,34 \\
& a_{54} \cdot a_{46}=2,94 \cdot 0,275=0,809 \cong a_{56}=0,81 \\
& a_{56} \cdot a_{62}=0,81 \cdot 0,5=0,405 \cong a_{52}=0,403 \\
& a_{47} \cdot a_{75}=0,44 \cdot 0,763=0,336 \cong a_{45}=0,34 \\
& a_{76} \cdot a_{62}=0,625 \cdot 0,5=0,312 \cong a_{72}=0,313 .
\end{aligned}
$$

Further, by the formula (6) we calculate the importance of resources. We have

$$
W_{M R}=\frac{\sum_{j=1}^{7} a_{1 j}}{\sum_{i=1}^{7} \sum_{j=1}^{7} a_{i j}}=\frac{38,4}{91,336}=0,42,
$$

$$
\begin{aligned}
& W_{F R}=\frac{\sum_{j=1}^{7} a_{2 j}}{\sum_{i=1}^{7} \sum_{j=1}^{7} a_{i j}}=\frac{20,164}{91,336}=0,22, \\
& W_{C R}=\frac{\sum_{j=1}^{7} a_{3 j}}{\sum_{i=1}^{7} \sum_{j=1}^{7} a_{i j}}=\frac{5,41}{91,336}=0,059 \cong 0,06, \\
& W_{O R}=\frac{\sum_{j=1}^{7} a_{4 j}}{\sum_{i=1}^{7} \sum_{j=1}^{7} a_{i j}}=\frac{2,785}{91,336}=0,03,
\end{aligned}
$$

\begin{tabular}{|c|c|c|c|c|c|}
\hline \multirow{2}{*}{ Indicator, years } & \multicolumn{5}{|c|}{ Actual value, c.u. } \\
\hline & 2013 & 2014 & 2015 & 2016 & 2017 \\
\hline 1 & 2 & 3 & 4 & 5 & 6 \\
\hline \multicolumn{6}{|c|}{ PJSC "Obolon" } \\
\hline $\begin{array}{l}\text { where: WMR - component of the vector for the } \\
\text { parameter "material resources", c.u.; }\end{array}$ & 2145735 & 2261079 & 1540790 & 1763509 & 2496994 \\
\hline $\begin{array}{l}F_{H R}-\text { component of the vector for the parameter } \\
\text { "human resources", c.u. }\end{array}$ & 323174 & 352133 & 292583 & 297351 & 279183 \\
\hline $\begin{array}{l}F_{C R}-\text { component of the vector for the parameter } \\
\text { "client resources", c.u. }\end{array}$ & 112982 & 125110 & 102473 & 105337 & 98624 \\
\hline $\begin{array}{l}F_{T R}-\text { component of the vector for the parameter } \\
\text { "technological resources", thousands UAH. }\end{array}$ & 234572 & 206976 & 162550 & 176696 & 175062 \\
\hline $\begin{array}{l}F_{F R}-\text { component of the vector for the parameter } \\
\text { "financial resources", c.u. }\end{array}$ & 753100 & 712855 & 639557 & 758118 & 377185 \\
\hline $\begin{array}{l}F_{O R}-\text { component of the vector for the parameter } \\
\text { "structural resources" }\end{array}$ & - & - & 2203 & 3459 & 3773 \\
\hline Total & 3569563 & 3658153 & 2737953 & 3101011 & 3427048 \\
\hline $\begin{array}{l}F_{G R}-\text { component of the vector for the parameter } \\
\text { "gender resources" }\end{array}$ & $320(21 / 79)$ & $957(25 / 76)$ & $909(28 / 72)$ & $991(31 / 69)$ & $967(28 / 72)$ \\
\hline
\end{tabular}$$
W_{H R}=\frac{\sum_{j=1}^{7} a_{5 j}}{\sum_{i=1}^{7} \sum_{j=1}^{7} a_{i j}}=\frac{8,196}{91,336}=0,0897 \approx 0.09,
$$$$
W_{T R}=\frac{\sum_{j=1}^{7} a_{6 j}}{\sum_{i=1}^{7} \sum_{j=1}^{7} a_{i j}}=\frac{10,086}{91,336}=0,11,
$$$$
W_{G R}=\frac{\sum_{j=1}^{7} a_{7 j}}{\sum_{i=1}^{7} \sum_{j=1}^{7} a_{i j}}=\frac{6,295}{91,336}=0,0089 \approx 0.07 .
$$

The received set of weight coefficients allows us to estimate the efficiency of enterprises on the basis and taking into account resource portfolios.

We will introduce the values of the elements of the resource portfolio for a number of enterprises in the brewing industry of Ukraine (Table 3).

Table 3

Values of elements of the resource portfolio for a number of enterprises of the brewing industry of Ukraine 
Continuation of Table 3

\begin{tabular}{|c|c|c|c|c|c|}
\hline 1 & 2 & 3 & 4 & 5 & 6 \\
\hline \multicolumn{6}{|c|}{ Zibert's Brewery LLC } \\
\hline $\begin{array}{l}\text { where: WMR - component of the vector for } \\
\text { the parameter "material resources", c.u.; }\end{array}$ & - & 47324 & 61493 & 94057 & 151388 \\
\hline $\begin{array}{l}F_{H R}-\text { component of the vector for the parameter } \\
\text { "human resources", c.u. }\end{array}$ & - & 11649 & 12698 & 16437 & 20490 \\
\hline $\begin{array}{l}F_{C R}-\text { component of the vector for the parameter } \\
\text { "client resources", c.u. }\end{array}$ & - & 4193 & 4582 & 5951 & 7288 \\
\hline $\begin{array}{l}F_{T R}-\text { component of the vector for the parameter } \\
\text { "technological resources", c.u. }\end{array}$ & - & 6812 & 8541 & 9046 & 10628 \\
\hline $\begin{array}{l}F_{F R}-\text { component of the vector for the parameter } \\
\text { "financial resources", c.u. }\end{array}$ & - & 8506 & 10555 & 26400 & 33129 \\
\hline $\begin{array}{l}F_{O R}-\text { component of the vector for the parameter } \\
\text { "structural resources" }\end{array}$ & - & - & 125,4 & 160 & 246 \\
\hline Total & - & 78484 & 97869 & 151891 & 222923 \\
\hline $\begin{array}{l}F_{G R}-\text { component of the vector for the parameter } \\
\text { "gender resources" }\end{array}$ & $487(23 / 77)$ & $498(23 / 77)$ & $501(21 / 79)$ & $423(22 / 78)$ & $375(25 / 75)$ \\
\hline \multicolumn{6}{|c|}{ PJSC "San In Bev Ukraine" } \\
\hline $\begin{array}{l}\text { where: WMR - component of the vector for } \\
\text { the parameter "material resources", c.u.; }\end{array}$ & - & 2364213 & 1785262 & 1691237 & 2055385 \\
\hline $\begin{array}{l}F_{H R}-\text { component of the vector for the parameter } \\
\text { "human resources", c.u. }\end{array}$ & - & 248177 & 244623 & 272159 & 309287 \\
\hline $\begin{array}{l}F_{C R}-\text { component of the vector for the parameter } \\
\text { "client resources", c.u. }\end{array}$ & - & 78401 & 79465 & 86912 & 80918 \\
\hline $\begin{array}{l}F_{T R}-\text { component of the vector for the parameter } \\
\text { "technological resources", c.u. }\end{array}$ & - & 581418 & 551097 & 557425 & 451835 \\
\hline $\begin{array}{l}F_{F R}-\text { component of the vector for the parameter } \\
\text { "financial resources", c.u. }\end{array}$ & - & 491023 & 731245 & 807300 & 840053 \\
\hline $\begin{array}{l}F_{O R}-\text { component of the vector for the parameter } \\
\text { "structural resources" }\end{array}$ & - & - & 3589 & 3629 & 4054 \\
\hline Total & - & 3763232 & 3391692 & 3415033 & 3737478 \\
\hline $\begin{array}{l}F_{G R}-\text { component of the vector for the parameter } \\
\text { "gender resources" }\end{array}$ & $398(21 / 79)$ & $869(25 / 75)$ & $798(24 / 76)$ & $936(28 / 72)$ & $923(24 / 76)$ \\
\hline \multicolumn{6}{|c|}{ PJSC "Carlsberg Ukraine" } \\
\hline $\begin{array}{l}F_{M R}-\text { component of the vector for the parameter } \\
\text { "material resources", c.u. }\end{array}$ & 1290122 & 1282459 & 1554372 & 1707823 & 2636128 \\
\hline $\begin{array}{l}F_{H R}-\text { component of the vector for the parameter } \\
\text { "human resources", c.u. }\end{array}$ & 207272 & 209318 & 232551 & 243740 & 257612 \\
\hline $\begin{array}{l}F_{C R}-\text { component of the vector for the parameter } \\
\text { "client resources", c.u. }\end{array}$ & 60025 & 63886 & 71600 & 72254 & 77396 \\
\hline $\begin{array}{l}F_{T R}-\text { component of the vector for the parameter } \\
\text { "technological resources", c.u. }\end{array}$ & 265865 & 292609 & 295577 & 302275 & 297814 \\
\hline $\begin{array}{l}F_{F R}-\text { component of the vector for the parameter } \\
\text { "financial resources", c.u. }\end{array}$ & 1046923 & 909108 & 633972 & 614017 & 715281 \\
\hline $\begin{array}{l}F_{O R}-\text { component of the vector for the parameter } \\
\text { "structural resources" }\end{array}$ & - & - & 2788 & 2940 & 3984 \\
\hline Total & 2870207 & 2757380 & 2788072 & 2940109 & 3984231 \\
\hline $\begin{array}{l}F_{G R}-\text { component of the vector for the parameter } \\
\text { "gender resources" }\end{array}$ & $501(22 / 78)$ & $936(24 / 76)$ & $912(26 / 74)$ & $870(25 / 75)$ & $897(28 / 72)$ \\
\hline
\end{tabular}

Now, for each enterprise, we define the structure of the resource portfolio, calculating the share of each resource in relation to their sum by the formulas:

$$
\begin{gathered}
\delta_{M R}=\frac{F_{M R}}{\Sigma}, \quad \delta_{H R}=\frac{F_{H R}}{\Sigma}, \quad \delta_{C R}=\frac{F_{C R}}{\Sigma}, \\
\delta_{T R}=\frac{F_{T R}}{\sum}, \quad \delta_{F R}=\frac{F_{F R}}{\sum}, \quad \delta_{O R}=\frac{F_{O R}}{\sum} .
\end{gathered}
$$

Finally, using data from Table 4 and the calculated set of values of weight coefficients, we find an estimate of the potential efficiency of enterprises by the formula (1).

\section{Structure of resource portfolios}

\begin{tabular}{|c|c|c|c|c|}
\hline $\begin{array}{c}\text { Re- } \\
\text { source }\end{array}$ & $\begin{array}{c}\text { PJSC } \\
\text { "Obolon" }\end{array}$ & $\begin{array}{c}\text { "Zibert's } \\
\text { Brewery" LLC }\end{array}$ & $\begin{array}{c}\text { PJSC "San In } \\
\text { Bev Ukraine" }\end{array}$ & $\begin{array}{c}\text { PJSC "Carls- } \\
\text { berg Ukraine" }\end{array}$ \\
\hline$\delta_{M R}$ & 0.728 & 0.68 & 0.55 & 0.66 \\
\hline$\delta_{F R}$ & 0.081 & 0.09 & 0.083 & 0.065 \\
\hline$\delta_{C R}$ & 0.029 & 0.03 & 0.024 & 0.019 \\
\hline$\delta_{O R}$ & 0.051 & 0.049 & 0.121 & 0.075 \\
\hline$\delta_{H R}$ & 0.11 & 0.15 & 0.225 & 0.179 \\
\hline$\delta_{T R}$ & 0.001 & 0.001 & 0.001 & 0.001 \\
\hline$\delta_{G R}$ & 0.28 & 0.25 & 0.24 & 0.28 \\
\hline
\end{tabular}


For each enterprise, the value was calculated

$$
R=\left(\delta_{M R}^{W_{M R}}\right)\left(\left(\delta_{H R}^{W_{H R}}\right)\left(\delta_{C R}^{W_{C R}}\right)\left(\delta_{T R}^{W_{T R}}\right) \delta_{F R}^{W_{F R}}\right)\left(\delta_{O R}^{W_{O R}}\right)\left(\delta_{E R}^{W_{E R}}\right) .
$$

At the same time, for PJSC "Obolon":

$$
\begin{aligned}
& R=(0,728)^{0,42} \cdot(0,081)^{0,09} \cdot(0,029)^{0,06} \times \\
& \times(0,051)^{0,11} \cdot(0,11)^{0,22} \cdot(0,001)^{0,03} \cdot(0,28)^{0,07}=0,186 ; \\
& \text { - for “Zibert's Brewery" LLC: }
\end{aligned}
$$$$
\begin{aligned}
& R=(0,68)^{0,42} \cdot(0,09)^{0,09} \cdot(0,03)^{0,06} \cdot(0,049)^{0,11} \times \\
& \times(0,15)^{0,22} \cdot(0,001)^{0,03} \cdot(0,25)^{0,07}=0,193
\end{aligned}
$$

- for PJSC “San In Bev Ukraine”:

$$
\begin{aligned}
& R=(0,55)^{0,42} \cdot(0,083)^{0,09} \cdot(0,024)^{0,06} \cdot(0,121)^{0,11} \times \\
& \times(0,225)^{0,22} \cdot(0,001)^{0,03} \cdot(0,24)^{0,07}=0,208 \\
& \text { - for PJSC “Carlsberg Ukraine”: }
\end{aligned}
$$

$$
\begin{aligned}
& R=(0,66)^{0,42} \cdot(0,065)^{0,09} \cdot(0,019)^{0,06} \cdot(0,075)^{0,11} \times \\
& \times(0,179)^{0,22} \cdot(0,001)^{0,03} \cdot(0,28)^{0,07}=0,198 .
\end{aligned}
$$

Thus, enterprises of the brewing industry, selected for the analysis by the degree of compliance of the structure of their resource portfolio to the formed hierarchy of resource importance are situated in the following sequence: "San In Bev", "Carlsberg", "Zibert's Brewery", "Obolon". It should be noted here that the results of calculations of the relative importance of private resources are entirely determined by the results of their expert assessment. The problem of compensation of the possible inaccuracy of these results leads to the need to improve the processing technology of the output data. Possible direction of research is the use of models of fuzzy [31] and inaccurate [32] mathematics. Methods of solving the problems arising in this case are proposed in [33-35].

In conclusion, let's consider the method of solving the target task of resource management of enterprises. Suppose there is a resource allocation, for example, the total volume of investments designed to create and maintain the required level of the set of private resources that form the vector $\mathrm{F}$ and determine the efficiency of enterprises. Let's introduce the dependence of the indicator of the enterprise efficiency on the volume of investment in private resources. For an analytic description of this dependence, we use the function (1):

$$
R(X)=\prod_{j=1}^{7} x_{j}^{w_{j}}
$$

where $x_{j}$ is the expedient investment in the $j$-th private resource; $\omega_{j}$ is the importance of $j$-th the resource.

The investment plan $X=\left(x_{1}, x_{2}, \ldots, x_{7}\right)$ must satisfy the limitations

$$
\sum_{j=1}^{7} x_{j}=C, \quad x_{j} \geq 0 .
$$

Then the task of rational allocation of the total amount of investment $C$ is formulated as follows: to form an opti- mal investment portfolio $X$, which maximizes the chosen resource provision (17) and satisfies the constraints (18). To solve the problem, we use the Lagrange's method of undetermined multipliers.

Let us introduce the Lagrange function:

$$
\Phi(x)=\prod_{j=1}^{7} x_{j}^{w_{j}}-\lambda\left(\sum_{j=1}^{7} x_{j}-C\right) .
$$

Then

$$
\frac{d \Phi(x)}{d x_{j}}=w_{j} x_{j}^{w_{j}-1} ; \prod_{i \neq j} x_{i}^{w_{i}}-\lambda=\frac{w_{j}}{x_{j}} ; \prod_{i=1}^{7} x_{i}^{w_{i}}-\lambda .
$$

Hence

$$
x_{j}=\frac{w_{i}}{\lambda} \prod_{i=1}^{7} x_{i}^{w_{i}}, \quad j=1,2, \ldots, 7 .
$$

Substituting (20) into (18), we find $\lambda$. We have

$$
\sum_{j=1}^{7} x_{j}=\frac{1}{\lambda} \prod_{i=1}^{7} x_{i}^{w_{i}}\left(\sum_{j=1}^{7} w_{j}\right)=C \text {. }
$$

Since, in accordance with (6),

$$
\sum_{j=1}^{n} w_{j}=1
$$

the relation (21) is simplified to the form:

$$
\frac{1}{\lambda} \prod_{j=1}^{7} x_{j}^{w_{j}}=C
$$

Where

$$
\lambda=\frac{\prod_{j=1}^{7} x_{j}^{w_{j}}}{C} .
$$

Now, substituting (22) into (20), we obtain the desired set

$$
x_{j}=\frac{w_{j} \cdot \prod_{j=1}^{7} x_{j}^{w_{j}}}{\prod_{j=1}^{7} x_{j}^{w_{j}}} \cdot C=w_{j} C, \quad j=1,2, \ldots, 7 .
$$

The expected result is: the share of the investment fund invested in the $j$-th resource is proportional to the importance of this resource. The proposed method is easily generalized to the case where the amount of investment in each resource can not be less than a certain threshold. If this threshold for $j$-th resource is equal to $C_{j}$, before solving the problem of finding a portfolio, it is necessary to deduct the sum of minimum values from the general investment fund and to solve the problem of distribution of the remaining fund

$$
C_{0}=C-\sum_{j=1}^{n} C_{j}
$$

in accordance with the above methodology. Thus, the structuring and parametrization of the task, the solution of which, taking into account the basic properties of resources, makes it possible to form an area of the man- 
agement system of resource provision of the enterprise, were carried out. The decision-making matrix using the comparative approach and the weighting factors of the resource tree elements, whose performance is matched by the T. Saati's hierarchy, can also be used to assess the effectiveness of the research results of resource provision of the enterprise. If structuring and parametrization are carried out taking into account the basic properties of resources, with the definition of their rank, this may be the groundwork for the formation of the basis and superstructure of the pyramidal structure of resources provision of the modern enterprise [36].

\section{Approbation of research results of resource provision of enterprises of the brewing industry of Ukraine}

Strengthening of the position of Ukrainian enterprises in the domestic and foreign markets depends on strategic management, substantiated regulation and introduction of an effective organizational and economic mechanism for the implementation of progressive changes, formation of a legal basis for conducting a successful innovation and investment policy. In this regard, a number of important issues remain to be solved for Ukrainian enterprises. Among them: the development and use of the gender component of the resource potential in business; restructuring and ensuring market transformation to increase the efficiency of entrepreneurial activity.

Approbation of the results of theoretical research was carried out on the example of brewing enterprises of the country. In particular, based on the results of research of the resource cost structure and identification of the main elements of the resource tree, the optimal (adapted to the current conditions) resource portfolio in the industry was calculated (Table 5).

According to the weight factors of the elements of the above resource portfolio, we can conclude that the most significant resources in the brewing industry are: material, financial, human and consumer. At the same time, it should be noted that the total amount of the intellectual component in the industry exceeds the traditional norm. In general, such a trend in the industry is positive, as the modern business environment prompts the actualization of the processes of intellectualization.

At the same time, it should be noted that gender aspects affect the process of resource provision of the enterprise. Thus, until recently brewing was considered to be a man's business, but today, at the head of the "Zibert's Brewery" LLC, there is a woman who has successfully restructured business, initiated a restructuring of the subsidiary company into the LLC and actively encourages the development of the craft segment.

According to the analysis of real data, one can conclude that each business entity in the industry has its own strategic resources, which confirms the uniqueness of each enterprise. For example, PJSC "Obolon" has a full cycle of production, which is fully equipped with material resources. Therefore, this enterprise focuses on the development of technological and customer resources. PJSC "SanInBev Ukraine" and PJSC "Carlsberg Ukraine" also have similar functional conditions as they are subsidiaries of transnational corporations.
Table 5

Adapted resource portfolio for breweries in Ukraine

\begin{tabular}{|c|c|c|c|c|}
\hline No. & Type of resource & $\begin{array}{c}\text { Share } \\
(\%)\end{array}$ & \begin{tabular}{|c|}
$\begin{array}{c}\text { Calcula- } \\
\text { tion }\end{array}$ \\
\end{tabular} & $\begin{array}{c}\text { Absolute } \\
\text { percentage, (\%) }\end{array}$ \\
\hline 1 & $\begin{array}{l}\text { FINANCIAL } \\
\text { RESOURCES }\end{array}$ & 22 & - & - \\
\hline 1.1. & Own funds & 50 & 0.5 & 25 \\
\hline 1.2. & Attracted funds & 35 & 0.35 & 12.25 \\
\hline 1.3. & Borrowed funds & 15 & 0.15 & 2.25 \\
\hline 2. & $\begin{array}{c}\text { MATERIAL } \\
\text { RESOURCES }\end{array}$ & 42 & - & - \\
\hline 2.1. & Raw resources & 65 & 0.65 & 42.25 \\
\hline 2.2. & Equipment & 20 & 0.2 & 4 \\
\hline 2.3. & Real estate & 10 & 0.1 & 1 \\
\hline 2.4. & Warehouse stocks & 5 & 0.05 & 0.25 \\
\hline 3 & HUMAN RESOURCES & 9 & - & - \\
\hline 3.1. & Experience & 25 & 0.25 & 6.25 \\
\hline 3.2. & Labour productivity & 50 & 0.5 & 25 \\
\hline 3.3. & Administrative system & 25 & 0.25 & 6.25 \\
\hline 4 & $\begin{array}{l}\text { ORGANIZATIONAL } \\
\text { RESOURCES }\end{array}$ & 3 & - & - \\
\hline 4.1. & Innovative activities & 15 & 0.15 & 2.25 \\
\hline 4.2. & Logistics management & 25 & 0.25 & 6.25 \\
\hline 4.3. & Information system & 15 & 0.15 & 2.25 \\
\hline 5 & CLIENT RESOURCES & 6 & - & - \\
\hline 5.1. & Supplier relations & 50 & 0.5 & 25 \\
\hline 5.2. & Customer relations & 50 & 0.5 & 25 \\
\hline 6 & GENDER RESOURCES & 7 & - & - \\
\hline 6.1. & Competencies & 25 & 0.25 & 6.25 \\
\hline 6.2. & Leadership & 35 & 0.35 & 12.25 \\
\hline 6.3. & Motivation & 40 & 0.4 & 16 \\
\hline 7 & $\begin{array}{c}\text { TECHNOLOGICAL } \\
\text { RESOURCES }\end{array}$ & 11 & - & - \\
\hline 7.1. & Recipe & 50 & 0.5 & 25 \\
\hline 7.2. & Technology & 50 & 0.5 & 25 \\
\hline & Total & 100 & - & 100 \\
\hline
\end{tabular}

Taking into account the high level of availability of traditional resources, enterprises of the brewing industry in Ukraine focus on the development of competency resources as an organizational ability to transform dynamic opportunities into transcendental resources, while creating sustainable competitive advantages. For example, the enterprise of the craft segment ("Zibert's Brewery" LLC) has a relatively low level of material resources, but wins due to the actualization of attention to improving the efficiency of the use of technological and client resources.

At the same time, the gender factor manifests itself on the enterprise. In recent years, the number of women in the LLC “Zibert's Brewery” has increased by $1-2 \%$ [37]. It is worth pointing out that the properties of resources are a dynamic characteristic, over time they can lose not only their uniqueness, but also value.

The calculations confirm the conclusions of the experts concerning the significance of material and human resources. Most business entities still have an underdeveloped intellectual component, which is the result of mostly conservative and extensive development. However, it should be noted that the enterprises of the craft segment in the industry adhere to the modern concept of resource theory. At the same time, accord- 
ing to the results of the research, it is possible to emphasize the necessity of developing not only the quality management system, but also the creation of a functional subsystem of resource management of enterprises' economic activity.

\section{Discussion of the results of the assessment of the resource provision of the enterprise}

A modern enterprise needs to improve the forms and methods of managing the resource system, in particular, taking into account the gender factor. Information support, increase of the scientific level, use of information technology are also of great importance. This will help the company to store all the details of the diagnosis, to exclude unexpected negative results of the interaction of different types of resources. The use of economic and mathematical methods to improve planning, forecasting, control, optimal distribution will contribute to the solution of this problem. An important way to improve the efficiency of enterprise resource management is also to train staff in accordance with gender peculiarities and in coordination with business interests. Increasing motivation of staff, application of innovative methods of resource management that envisage the implementation of scientific and technological advances in the daily business activities of companies.

The studies confirm the conclusions of industry experts concerning the importance of intellectual resource components for the development of a socially-oriented modern enterprise. It should be noted that the majority of Ukrainian business entities still have an undeveloped intellectual component of the resource portfolio, which is a consequence of conservative and extensive development. It should also be noted that the enterprises of the craft segment adhere to the modern concept of resource theory. At the same time, the necessity of development not only of the quality management system, but the creation of a functional subsystem of resource management of the economic activity of the enterprise should be emphasized.

As one of the important results of the research, it is useful to note that the necessary condition for the effective use of strategic resources is the continuous search for opportunities to obtain resource effects from optimal use of the potential of strategic resources of the company. Their combination provides generation of additional cash flows or formation of transcendental resources. Optimal use of the potential of existing strategic resources is an important task of the company management. If the management made a false assessment of the strategic resources, then the existing business development strategy will not receive the necessary resources.

Consequently, we can conclude that all the enterprises under study, have the resource potential and a wide range of opportunities that need to be transformed into sustainable competitive advantages. Undoubtedly, for the strategic development of economic activity, management should review the approaches to resource management of enterprises. Most of the enterprises are still in the "deception", focusing first of all on the development of the management system of material resources, which for today are not unique resources. The beer market is quite saturated with a high level of competition, therefore, it is necessary to more effectively use the dynamic opportunities of the business environment, which will become the basis for strategic development and provide a stable competitive advantage.

\section{Conclusions}

1. The peculiarities of the influence of gender aspects on resource provision of the enterprise were investigated. It was determined that for each economic entity, there are individual resource combinations that form resource asymmetry and increase the level of competitiveness of the enterprise. Determining the impact of gender aspects on the resource provision of the enterprise activates the creation of its own organizational competencies and enables to identify and develop unique capabilities of resources that will ensure the implementation of effective business activities of the enterprise.

2 . The model of the process of resource provision management of the enterprise was proposed, taking into account the existing influence of the gender factor on the efficiency of business processes on the basis of integrated assessment of the importance of the elements of the resource portfolio by expert methods. The model is based on the construction of a formalized matrix of resource priorities and the calculation of the importance of the elements of the resource portfolio, based on factors such as uniqueness, substitution, value, sufficiency, mobility, timeliness, and complementarity, and using the index of coherence to reduce the subjectivity of the evaluation.

3. Elemental components of the resource portfolio of the enterprise for ensuring the efficiency of business processes at the enterprise are identified and systematized. The components of the resource portfolio include the following components: material, financial, client, structural, human and gender. Fundamental novelty in the systematization of elements of resource provision of the enterprise is finding conditions that give the company competitive advantages at its own resource equilibrium, focusing on organizational reasons for the differentiation of the components of the resource portfolio and their profitability.

4. The expediency of implementation of the developed model of identification of key elements of the resource portfolio for enterprises of the brewing industry of Ukraine is substantiated. According to the weight factors of the elements of the resource portfolio, we can conclude that the most significant resources in the brewing industry are: material, financial, human and consumer. Taking into account the high level of availability of traditional resources, enterprises of the brewing industry in Ukraine focus on the development of intellectual (competency) resources, as an organizational ability to transform dynamic capabilities into transcendental resources, while creating sustainable competitive advantages.

\section{References}

1. Sarfaraz L., Faghih N., Majd A. The relationship between women entrepreneurship and gender equality // Journal of Global Entrepreneurship Research. 2014. Vol. 2, Issue 1. P. 6. doi: https://doi.org/10.1186/2251-7316-2-6

2. Jennings J. E., Brush C. G. Research on Women Entrepreneurs: Challenges to (and from) the Broader Entrepreneurship Literature? // Academy of Management Annals. 2013. Vol. 7, Issue 1. P. 663-715. doi: https://doi.org/10.5465/19416520.2013.782190 
3. Intelligent Manufacturing in the Context of Industry 4.0: A Review / Zhong R. Y., Xu X., Klotz E., Newman S. T. // Engineering. 2017. Vol. 3, Issue 5. P. 616-630. doi: https://doi.org/10.1016/j.eng.2017.05.015

4. Andriushchenko K. The formation of the system of intellectual capital management at enterprises // Technology audit and production reserves. 2017. Vol. 2, Issue 4 (34). P. 4-9. doi: https://doi.org/10.15587/2312-8372.2017.98178

5. Andriushchenko K., Shergina L., Kovtun V. Analysis of peculiarities and prospects of development of Ukraine in the concept of industry 4.0 // Technology audit and production reserves. 2018. Vol. 4, Issue 5 (42). P. 36-41. doi: https://doi.org/ $10.15587 / 2312-8372.2018 .142354$

6. Andriushchenko K. The Impact of Gender Affiliation on Business Interaction in Entrepreneurship // II International scientific conference Economy and Society: a Modern Vectors of Development. Leipzig, 2018. P. 111-114.

7. Andriushchenko K. Effective use of tools for knowledge of gender aspects in entrepreneurship // II International scientific conference "The modern trends in the development of business social responsibility". Lisbon, 2018. P. 65-67.

8. Andersén J. Resource-based competitiveness: managerial implications of the resource based view // Strategic Direction. 2010. Vol. 26, Issue 5. P. 3-5. doi: https://doi.org/10.1108/02580541011035375

9. Koetter F., Kochanowski M. A model-driven approach for event-based business process monitoring // Information Systems and e-Business Management. 2014. Vol. 13, Issue 1. P. 5-36. doi: https://doi.org/10.1007/s10257-014-0233-8

10. Koperek J., Koperek A., Kome A. Today's threats of human rights in the context of protection of the right to life // Scientific Journal of Polonia University. 2018. Vol. 29, Issue 4. P. 128-134. doi: https://doi.org/10.23856/2915

11. Baran M., Kłos M. Managing an intergenerational workforce as a factor of company competitiveness // Journal of International Studies. 2014. Vol. 7, Issue 1. P. 94-101. doi: https://doi.org/10.14254/2071-8330.2014/7-1/8

12. Modern tools for evaluating of the company competitiveness resource based advantages theory / Radko V., Matsyura S., Nikolaichuk O., Viskers E. // Scientific Journal of Polonia University. 2017. Vol. 24, Issue 5. P. 76-81. doi: https://doi.org/ $10.23856 / 2408$

13. Nikolaichuk O., Matukova G. Enterprise human capital management in the conditions of innovative economy // Scientific Journal of Polonia University. 2016. Vol. 18, Issue 3. P. 137-144. doi: https://doi.org/10.23856/1815

14. Terpstra D. E., Limpaphayom W. Using Evidence-Based Human Resource Practices for Global Competitiveness // International Journal of Business and Management. 2012. Vol. 7, Issue 12. doi: https://doi.org/10.5539/ijbm.v7n12p107

15. Andriushchenko K. Global trends of gender parity for women entrepreneurs // International scientific conference The Formation of a Modern Competitive Environment: Integration and Globalization. Greenwich, 2018. P. 115-118.

16. Xiang G., Bo W. Research on enterprise human resource competitiveness based on BP ANN // 2010 3rd International Conference on Computer Science and Information Technology. 2010. doi: https://doi.org/10.1109/iccsit.2010.5564907

17. Francis D. Culture, Power Asymmetries and Gender in Conflict Transformation // Transforming Ethnopolitical Conflict. 2004. P. 91-107. doi: https://doi.org/10.1007/978-3-663-05642-3_5

18. Davis M. H., Capobianco S., Kraus L. A. Gender Differences in Responding to Conflict in the Workplace: Evidence from a Large Sample of Working Adults // Sex Roles. 2010. Vol. 63, Issue 7-8. P. 500-514. doi: https://doi.org/10.1007/s11199-010-9828-9

19. Kark R., Waismel-Manor R., Shamir B. Does valuing androgyny and femininity lead to a female advantage? The relationship between gender-role, transformational leadership and identification // The Leadership Quarterly. 2012. Vol. 23, Issue 3. P. 620-640. doi: https://doi.org/10.1016/j.leaqua.2011.12.012

20. Ramadoss K., Rajadhyaksha U. Gender Differences in Commitment to Roles, Work-family Conflict and Social Support // Journal of Social Sciences. 2012. Vol. 33, Issue 2. P. 227-233. doi: https://doi.org/10.1080/09718923.2012.11893101

21. Brenner O. C., Tomkiewicz J., Schein V. E. Research notes. The relationship between sex role stereotypes and requisite management characteristics revisited // Academy of Management Journal. 1989. Vol. 32, Issue 3. P. 662-669. doi: https://doi. org/10.2307/256439

22. Afzalur Rahim M. Toward a theory of managing organizational conflict // International Journal of Conflict Management. 2002. Vol. 13, Issue 3. P. 206-235. doi: https://doi.org/10.1108/eb022874

23. Gender and work: representations of femininities and masculinities in the view of women brazilian executives / Carrieri A. de P., Diniz A. P. R., Souza E. M. de, Menezes R. S. S. // BAR - Brazilian Administration Review. 2013. Vol. 10, Issue 3. P. $281-303$. doi: https://doi.org/10.1590/s1807-76922013005000002

24. Brewer N., Mitchell P., Weber N. Gender role, organizational status, and conflict management styles // International Journal of Conflict Management. 2002. Vol. 13, Issue 1. P. 78-94. doi: https://doi.org/10.1108/eb022868

25. Sherifat Y. O. Gender differentials in factors affecting performance of small-scale enterprises in Lagos state - Nigeria // Innovative Issues and Approaches in Social Sciences. 2013. Vol. 6, Issue 2. P. 21-39.

26. Pinquart M., Sorensen S. Gender Differences in Caregiver Stressors, Social Resources, and Health: An Updated Meta-Analysis // The Journals of Gerontology Series B: Psychological Sciences and Social Sciences. 2006. Vol. 61, Issue 1. P. P33-P45. doi: https:// doi.org/10.1093/geronb/61.1.p33 
27. Westermann O., Ashby J., Pretty J. Gender and social capital: The importance of gender differences for the maturity and effectiveness of natural resource management groups // World Development. 2005. Vol. 33, Issue 11. P. 1783-1799. doi: https:// doi.org/10.1016/j.worlddev.2005.04.018

28. Metcalfe B. D. Gender and human resource management in the Middle East // The International Journal of Human Resource Management. 2007. Vol. 18, Issue 1. P. 54-74. doi: https://doi.org/10.1080/09585190601068292

29. Saati T. Decision making by analyzing hierarchies. Moscow: Radio and communication, 1989. 316 p.

30. Seraya O. V. Mnogomernye modeli logistiki v usloviyah neopredelennosti. Kharkiv: FOP Stecenko, 2010. 512 p.

31. Raskin L. G., Seraya O. V. Nechetkaya matematika. Kharkiv: Parus, 2008. 352 p.

32. Pawlak Z. Rough sets // International Journal of Computer \& Information Sciences. 1982. Vol. 11, Issue 5. P. 341-356. doi: https://doi.org/10.1007/bf01001956

33. Sira O. V., Al-Shqeerat K. H. A New Approach for Resolving Equations with Fuzzy Parameters // European Journal of Scientific Research. 2009. Vol. 38, Issue 4. P. 619-625.

34. Raskin L., Sira O. Fuzzy models of rough mathematics // Eastern-European Journal of Enterprise Technologies. 2016. Vol. 6, Issue 4 (84). P. 53-60. doi: https://doi.org/10.15587/1729-4061.2016.86739

35. Raskin L., Sira O. Method of solving fuzzy problems of mathematical programming // Eastern-European Journal of Enterprise Technologies. 2016. Vol. 5, Issue 4 (83). P. 23-28. doi: https://doi.org/10.15587/1729-4061.2016.81292

36. Teplyuk M. Management of resource support of the activity of brewing enterprises in the conditions of globalization of the national economy // Collection of All-Ukrainian Scientific and Practical Conference with International Participation: "Strategies, Problems and Regulation of Economic Systems in Conditions of Macroeconomic Instability". Mykolaiv, 2016. P. $100-104$.

37. Teplyuk M. Modern tendencies of development of enterprises of the brewing industry of Ukraine // Collection of All-Ukrainian Scientific and Practical Internet. conference: "Innovative enterprise: the state and prospects of development" Kyiv, 2016. 